PAULA, E.M.N. et al. Características epidemiológicas da Leucemia Viral Felina. PUBVET, Londrina, V. 8, N. 16, Ed. 265, Art. 1764, Agosto, 2014.

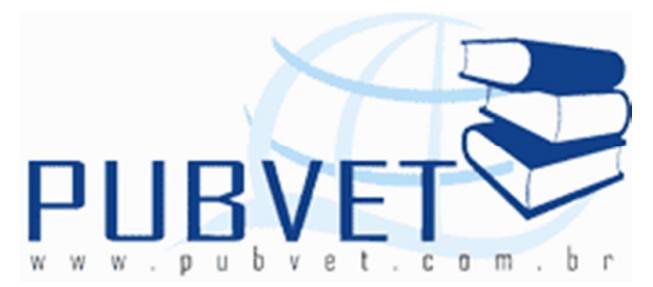

PUBVET, Publicações em Medicina Veterinária e Zootecnia.

\title{
Características epidemiológicas da Leucemia Viral Felina
}

Eric Mateus Nascimento de Paula ${ }^{1}$, Carolina de Alvarenga $\mathrm{Cruz}^{2}$, Fernanda Cassioli de Moraes $^{2}$, Daniel Bartoli de Sousa ${ }^{3}$, Raphaella Barbosa Meirelles-Bartoli ${ }^{3}$

${ }^{1}$ Aluno do Curso de Medicina Veterinária da Universidade Federal de Goiás, Campus Jataí.

${ }^{2}$ Alunas do Curso de Pós-Graduação em Medicina Veterinária, Faculdade de Ciências Agrárias e Veterinárias, UNESP, Campus Jaboticabal.

${ }^{2}$ Docentes do Curso de Medicina Veterinária da Universidade Federal de Goiás (UFG), Campus Jataí, Unidade Jatobá, Laboratório de Sanidade Animal.

\section{Resumo}

O vírus da Leucemia Viral Felina (FeLV) é um Gammaretrovírus, da família Retroviridae, que é transmitido, principalmente, pela exposição oronasal e afeta tanto gatos domésticos quanto, felinos selvagens, debilitando o sistema imunológico. A doença tem grande relação com alta densidade populacional e pode ser transmitida pela saliva, sangue, urina, via transplacentária dentre outros. É uma doença que pode se apresentar tanto de forma neoplásica quanto não neoplásica e imunossupressora, e sua gravidade varia dependendo das características genéticas da variante infectante do vírus. O tratamento da FeLV é de acordo com a doença secundária e no caso das neoplasias, a quimioterapia associada pode ser relativamente eficaz.

Palavras-chave: Felinos, FeLV, Gammaretrovírus. 
PAULA, E.M.N. et al. Características epidemiológicas da Leucemia Viral Felina. PUBVET, Londrina, V. 8, N. 16, Ed. 265, Art. 1764, Agosto, 2014.

\title{
Epidemiological characteristics of Feline Viral Leukemia
}

\begin{abstract}
Feline Leukaemia Virus (FeLV) is a Gammaretrovirus, the Retroviridae family, which is transmitted mainly by oronasal exposure and affects as much as domestic cats, wild cats, weakening the immune system. The disease is strongly associated with high population density and can be transmitted by saliva, blood, urine, transplacentally among others. It is a disease that can present both neoplastic and non-neoplastic form and immunosuppressive, and its severity varies depending on the genetic characteristics of the infecting virus variant. The treatment according to FeLV is the secondary disease and in the case of neoplasms, systemic chemotherapy may be relatively effective.
\end{abstract}

Keywords: Feline, FelV, Gammaretrovirus

\section{INTRODUÇÃo}

O vírus da Leucemia Viral Felina (FeLV) é transmitido principalmente pelo contato direto frequente ou prolongado entre animais e pela ingestão de água e comida contaminadas (HOOVER, MULLINS, 1991 citado por TEIXEIRA et al, 2007). O vírus também pode ser transmitido pelas secreções respiratórias, lacrimais, pelo leite, urina e fezes (ARJONA et al, 2000 citado por TEIXEIRA et al, 2007), além de ser possível a transmissão venérea e durante a gestação (HARBOUR et al, 2002 citado por TEIXEIRA et al, 2007).

O vírus da FeLV é possivelmente a maior causa isolada, atraumática, de morte para gatos adultos (JARRET, 1988). Uma das mais notáveis características deste vírus em relação aos outros retrovírus felinos é que muitos gatos expostos a ele se recuperam, e tornam-se não virêmicos (SOUZA e TEIXEIRA, 2003).

O curso progressivo da infecção pelo vírus da FeLV nos felinos é caracterizado por viremia persistente, resposta imunológica antiviral ineficaz em uma parcela considerável dos gatos infectados, imunossupressão e disfunção hematológica e hematopoética que, em estágio terminal, resultam 
PAULA, E.M.N. et al. Características epidemiológicas da Leucemia Viral Felina. PUBVET, Londrina, V. 8, N. 16, Ed. 265, Art. 1764, Agosto, 2014.

em várias doenças e síndromes clínicas proliferativas e degenerativas (HAGIWARA; JUNQUEIRA-JORGE; STRICAGNOLO, 2007).

$\mathrm{O}$ vírus da FeLV é um significante patógeno dos gatos domésticos que causa uma variedade de desordens neoplásicas e degenerativas, incluindo linfomas, sarcomas, imunodeficiência. A severidade da doença é intimamente dependente das características genéticas da variante infectante do vírus (SOUZA; TEIXEIRA, 2003).

Os gatos são usualmente infectados a partir do estreito e íntimo contato com portadores do vírus da FeLV, através de mordidas, cuidado mútuos com os pelos, e pelo uso em comum de vasilhas sanitárias e fômites de água e comida. A incidência é maior nos animais que se situam na faixa etária de um a cinco anos (SOUZA; TEIXEIRA, 2003). Gatos jovens, que vivem em grupos com contato íntimo entre os animais são mais susceptíveis à infecção (HOOVER, MULLINS, 1991 citado por TEIXEIRA et al, 2007).

Uma das mais notáveis características do vírus da FeLV em relação aos outros retrovírus felinos é que muitos gatos expostos ao vírus se recuperam, e tornam-se não virêmicos (SOUZA; TEIXEIRA, 2003).

No Brasil, já foi detectada por meio de pesquisas sorológicas e pela PCR, em gatos domésticos domiciliares e de rua, nos estados de São Paulo, Rio de Janeiro, Rio Grande do Sul e Minas Gerais, com prevalências que variam de 8,0\% a 63,0\% (CALDAS et al., 2000; SOUZA et al., 2002; CAXITO, 2003; ALMEIDA et al., 2004 citado por TEIXEIRA et al, 2007).

\section{DEFINIÇÃO}

Doença infecciosa causada por um retrovírus, do gênero Gammaretrovírus, que causa imunodeficiência e doença neoplásica em gatos domésticos (BARR, 2008). Além disso, como todas as doenças causadas por retrovírus, a FeLV estabelece uma infecção permanente em seu hospedeiro (JARRET e HOSIE, 2006), e sua severidade é intimamente dependente das características genéticas da variante infectante do vírus (SOUZA e TEIXEIRA, 2003). 
PAULA, E.M.N. et al. Características epidemiológicas da Leucemia Viral Felina. PUBVET, Londrina, V. 8, N. 16, Ed. 265, Art. 1764, Agosto, 2014.

O vírus da FeLV está amplamente reconhecido pela sua transmissão contagiosa entre os gatos, induz à doença e leva à morte mais pacientes que qualquer outro processo patológico (LOAR, 1993 citado por SOUZA; TEIXEIRA, 2003).

\section{HISTÓRICO}

O vírus da FeLV se originou milhões de anos atrás através da transmissão cruzada entre espécies de retrovírus endógenos de rato, para os ancestrais do gato moderno (BARR, 2008). Foi o primeiro retrovírus descoberto nos gatos domésticos por William Jarrett, em 1964. Esse vírus foi isolado durante as investigações clínicas da possível causa da ocorrência de múltiplos casos de linfossarcorma em gatos pertencentes a um abrigo (SOUZA; TEIXEIRA, 2003). Jarret e colaboradores foram os responsáveis pela primeira inoculação de gatinhos neonatos com uma suspensão obtida de linfonodos felinos linfomatosos (JONES et al., 2000), apesar de poucos isolados terem sido obtidos, pois foi impossível isolar o vírus da maioria dos tumores em que esperava-se encontrá-lo. No entanto, a presença do genoma viral foi demonstrada por hibridação e transinfecção, e assim, foi sugerido que a replicação viral e sua liberação não são necessárias para ocorrer a doença (MURPHY et al., 1999).

O vírus da FeLV foi reconhecido a mais de quatro décadas, como um retrovírus imunossupressivo e leucemogênico transmitido pelo contágio direto (HAGIWARA; JUNQUEIRA-JORGE; STRICAGNOLO, 2007).

\section{IMPORTÂNCIA DA DOENÇA}

Se tratando dos aspectos de saúde pública deste vírus, existem numerosos estudos, mas nenhum deles encontrou uma ligação entre o vírus da FeLV e qualquer doença humana. Recomenda-se que neonatos e indivíduos imunodeficientes evitem manter contato com gatos com resultado positivo para infeç̧ão pelo vírus da FeLV. Possivelmente um gato imunossuprimido pelo vírus possa transmitir outros patógenos em maior número com potencial 
PAULA, E.M.N. et al. Características epidemiológicas da Leucemia Viral Felina. PUBVET, Londrina, V. 8, N. 16, Ed. 265, Art. 1764, Agosto, 2014.

zoonótico do que os gatos normais, mas esta teoria não tem sido bem documentada (SOUZA; TEIXEIRA, 2003).

Animais infectados, com o sistema imunitário comprometido, tem uma capacidade limitada de resposta imune frente à maioria das infecções, sejam elas causadas por bactérias, fungos ou vírus (BLEICH, 1988); podendo acarretar perdas econômicas para os estabelecimentos de criação e reprodução desses animais.

\section{ETIOLOGIA}

A classificação dos retrovírus é complexa. Atualmente, os retrovírus são divididos em sete gêneros: retrovírus alfa, retrovírus beta, retrovírus gama, retrovírus delta, retrovírus épsilon, lentivírus e spumavírus. Os gatos são infectados por retrovírus representantes de três gêneros:

1) Spumavírus - tendo como representante o vírus formador de sincício felino (FeSFV) que induz a uma infecção persistente, mas não aparente, sem evidência de patogênese ao hospedeiro; é prevalente em gatos de vida livre e parece ser distribuído por mordedura;

2) Retrovírus gama - incluindo o vírus da leucemia felina (FeLV);

3) Lentivírus - compreendendo o vírus da imunodeficiência dos felinos (FIV) (SOUZA; TEIXEIRA, 2003).

O vírus da FeLV é um retrovírus oncogênico envelopado medindo $110 \mathrm{~nm}$ de diâmetro composto de uma fita simples de RNA (acido ribonucleico) que é transcrito pela enzima transcriptase reversa. O FeLV possui três genes internos que codificam as proteínas do núcleo ( $g a g)$, as proteínas do envoltórios (env), e a enzima transcriptase reversa $(p o /)$. Os retrovírus possuem um envoltório externo no qual estão inseridas as glicoproteínas virais (gp70) que permitem sua ligação com a célula. Essas proteínas representam o alvo para os anticorpos neutralizantes produzidos pelo sistema imunológico do hospedeiro. A ligação dessas glicoproteínas com a membrana citoplasmática é feita por uma pequena molécula protéica não glicosada, a p15E, que desempenha um 
PAULA, E.M.N. et al. Características epidemiológicas da Leucemia Viral Felina. PUBVET, Londrina, V. 8, N. 16, Ed. 265, Art. 1764, Agosto, 2014.

papel importante como mediadora da imunossupressão e da anemia. As gp70 interagem com receptores existentes em inúmeras células, o que permite a replicação do vírus em uma multiplicidade de células do organismo animal infectado. Gatos capazes de produzir anticorpos neutralizantes contra a gp70 em níveis significativos, após a infecção inicial, são também capazes de eliminar completamente o agente etiológico, livrando-se da infecção. Dentre as várias proteínas do núcleo, a p27 tem maior significância, pois é através desse antígeno que se detecta o vírus nos testes para o vírus da FeLV (SOUZA; TEIXEIRA, 2003).

\subsection{ASPECTOS PATOGÊNICOS}

Há quatro subgrupos do vírus da FeLV: FeLV-A, FeLV-B, FeLV-C e FeLVT. Estes subgrupos são distinguidos pelos receptores da célula e parecem regular quando e que tipo de doença ocorrerá (SOUZA; TEIXEIRA, 2003).

Nos gatos virêmicos durante o longo período de incubação quando o vírus da FeLV se eleva a altos títulos no hospedeiro, há uma ampla oportunidade para alterações genéticas ocorrerem no vírus, como também, recombinações entre o FeLV-A e os genes celulares produzindo o vírus da leucemia "aguda". As sequências endógenas relacionadas com o vírus da FeLV são incompletas, e, portanto, incapazes de descrever vírions intactos, mas a recombinação do provírus de FeLV-A integrado com essas sequências geram novos subgrupos, o FeLV-B e o FeLV-T (vírus com tropismo pelos linfócitos T). É possível que estes vírus possam ter uma vantagem seletiva para replicação uma vez que eles emergem num gato infectado pelo FeLV-A, porque eles podem burlar a interferência viral contra o progenitor FeLV-A. Provavelmente, mutações ocorrem no sítio de ligação do receptor no região hipervariável I do gene que codifica a proteína do envoltório do FeLV-A, gerando o FeLV-C (SOUZA; TEIXEIRA, 2003).

O FeLV-A é a forma transmissível do vírus, presumivelmente porque as células que expressam o receptor para esses vírus, são as células-alvo no sítio de infecção inicial ou na amplificação viral no hospedeiro. O subgrupo FeLV-A 
PAULA, E.M.N. et al. Características epidemiológicas da Leucemia Viral Felina. PUBVET, Londrina, V. 8, N. 16, Ed. 265, Art. 1764, Agosto, 2014.

está presente em todos os animais positivos, podendo estar acompanhado do FeLV-B e do FeLV-C, ou de ambos, pois sem o FeLV-A, o FeLV-B e o FeLV-C não conseguem penetrar na célula nem realizar a replicação. A sequência dos genes do envoltório de FeLV-A que circulam na população de gatos é bastante conservada e notavelmente estável, em contraste com a variabilidade vista em populações com FIV (SOUZA; TEIXEIRA, 2003).

Por si só, o FeLV-A é o subgrupo menos patogênico, e as infecções nos gatos adultos geralmente resultam em viremia transitória com, ou sem, um período subsequente de infecção latente. Em gatinhos jovens, este subgrupo pode causar uma anemia hemolítica e eventualmente levar ao desenvolvimento de linfoma. No entanto, há evidências de um maior risco de desenvolvimento de linfoma em gatos infectados com uma mistura dos subgrupos FeLV-A e FeLV-B, quando comparada com infecções apenas por FeLV-A. Em contraste, o FeLV-B é encontrado com o FeLV-A em alguns, mas não em todos os gatos cronicamente infectados, e é muito pobremente transmitidos mesmo em altas doses (SOUZA; TEIXEIRA, 2003).

O subgrupo FeLV-B, uma vez enxertado, pode causar moléstia mieloproliferativa ou mielossupressora, enquanto que o subtipo FeLV-C está relacionado com o rápido desenvolvimento de um tipo específico de anemia caracterizado por uma completa interrupção da diferenciação eritróide. Alterações específicas nos aminoácidos e uma pequena inserção na proteína do envoltório resultam na emergência de um variante citopático, o FeLV-T, que causa depleção linfoide e imunodeficiência. A especificidade celular do FeLV-T surge devido a um co-fator requerido para a entrada do FeLV-T, sendo mais altamente expressado em células linfoides (SOUZA; TEIXEIRA, 2003).

\section{EPIDEMIOLOGIA}

\subsection{Distribuição Geográfica}

A infecção dos felinos domésticos pelo vírus da FeLV apresenta distribuição mundial, com prevalência relativamente: de 1 a $8 \%$ nos gatos sadios e de 12 a mais de $30 \%$ entre os felinos doentes ou em grupos de 
PAULA, E.M.N. et al. Características epidemiológicas da Leucemia Viral Felina. PUBVET, Londrina, V. 8, N. 16, Ed. 265, Art. 1764, Agosto, 2014.

animais, nos quais a infecção foi recentemente introduzida. A incidência da infecção é significativamente maior em gatos que tem acesso à rua do que entre os animais confinados (HAGIWARA; JUNQUEIRA-JORGE; STRICAGNOLO, 2007).

\subsection{Cadeia Epidemiológica}

\subsubsection{Fonte de infecção}

O vírus da FeLV pode infectar tanto os gatos domésticos como outros felinos selvagens, tendo sido descrita a infecção no Felis silvestris. O maior determinante dos limites do hospedeiro é a especificidade do subgrupo (SOUZA; TEIXEIRA, 2003).

\subsubsection{Vias de eliminação}

Os gatos que desenvolvem a viremia persistente eliminam o vírus na maioria das secreções corporais (especialmente da saliva) e consequentemente eles são contagiosos a outros gatos (SHERDING, 1998). O gato assintomático persistentemente virêmico, pode eliminar até um milhão de partículas virais em cada mililitro de saliva (AUGUST, 1992; COUTO, 1994; NORSWORTHY, 1993 citado por SOUZA; TEIXEIRA, 2003).

Os gatos infectados eliminam o vírus da FeLV através da saliva, urina e fezes (ROJKO; HARDY, 1994; ROMATOWSKI; LUBKIN, 1997 citado por SOUZA; TEIXEIRA, 2003). Embora o vírus se replique no epitélio da mucosa da bexiga e intestino, o vírus infectante é pouco preservado na urina e nas fezes (ROMATOWSKI; LUBKIN, 1997 citado por SOUZA; TEIXEIRA, 2003). Ainda há relatos que o vírus da FeLV está presente em todos os líquidos corporais incluindo plasma, leite e lágrimas (AUGUST, 1992; LAPPIN, 1998 citado por SOUZA; TEIXEIRA, 2003).

Existe ainda citações de eliminação por mordeduras, acasalamento e secreções contaminadas (MEINERZ et al., 2010). 
PAULA, E.M.N. et al. Características epidemiológicas da Leucemia Viral Felina. PUBVET, Londrina, V. 8, N. 16, Ed. 265, Art. 1764, Agosto, 2014.

\subsubsection{Meios de transmissão}

A transmissão ocorre mediante a exposição à urina, lágrima, leite, sangue, saliva, mordedura ou contato com material contaminado como alimentos, água ou caixas de micção e defecação, transfusão sanguínea e fômites (BARR, 1997; PEDERSEN, 1987 citado por BARBOSA; CHRISTIANINE; WALDEMARIN, 2001). A transmissão do vírus da FeLV pela saliva infectada é facilitada pelo comportamento social dos felinos, principalmente em locais com elevada densidade populacional de animais, onde lambidas, mordidas (até para o acasalamento) e o desfrute dos mesmo fômites e vasilhas sanitárias são frequente entre eles (LAPPIN, 1998; MEHL, 2001; ROJKO E HARDY 1994; ROMATOWSKI; LUBKIN, 1997 citado por SOUZA; TEIXEIRA, 2003).

Os felinos que mantem contato próximo e prolongado com os portadores são aqueles que apresentam maior probabilidade de se infectarem, justificando-se assim, a alta frequência da infecção em animais que vivem em abrigos ou domicílios com outros gatos (MUIRDEN, 2002 citado por HAGIWARA, JORGE, STRICAGNOLO, 2007). A doença é transmitida horizontalmente por contato oronasal que é a mais importante, ocorre ainda através do contato intimo de gatos suscetíveis com gatos infectados (ROJKO; HARDY, 1994; ROMATOWSKI; LUBKIN, 1997 citado por SOUZA; TEIXEIRA, 2003). Através de lambidas, mordidas ou mesmo espirros pode ter transmissão e, com menos frequência pode ocorrer a transmissão vertical da mãe para o feto, através da via placentária ou do leite, todos os tipos de transmissão citados acima são de transmissão direta (BLEICH, 1988).

A transmissão da infecção pelo leite e pela placenta pode ocorrer em fêmeas matrizes virêmicas (AUGUST, 1992; MEHL, 2001; ROJKO; HARDY, 1994 citado por SOUZA; TEIXEIRA, 2003). Os gatinhos neonatos que escapam à infecção via útero ou leite materno tornar-se-ão infectados com a saliva da gata matriz virêmica, durante os cuidados de limpeza e higiene (AUGUST, 1992 citado por SOUZA; TEIXEIRA, 2003). Havendo relatos que em $80 \%$ dos casos de transmissão transplacentária, ocorre morte fetal ou neonatal, outros $20 \%$ podem nascer infectados e permanecem como portadores (BARBOSA; 
PAULA, E.M.N. et al. Características epidemiológicas da Leucemia Viral Felina. PUBVET, Londrina, V. 8, N. 16, Ed. 265, Art. 1764, Agosto, 2014.

CHRISTIANINE; WALDEMARIN, 2001). Ocorre ainda a possibilidade de o vírus ser transmitido por pulgas através da sucção de sangue contaminado, transmitido a outros animais através da picada, essa uma transmissão indireta que é transmitida por um vetor (BLEICH, 1988).

\subsubsection{Porta de entrada}

O vírus penetra no organismo através da mucosa dos olhos, do nariz e da boca ou através de soluções de continuidade, entrando na circulação sanguínea, alojando-se em vários órgãos e tecidos, onde ocorre a sua replicação. Após este processo, o vírus pode voltar novamente à circulação, atingindo vários outros órgãos (BLEICH, 1988).

\subsubsection{Hospedeiros susceptíveis}

Os hospedeiros susceptíveis são os hospedeiros vertebrados que se infectam com o vírus da FeLV. Relatos da presença deste vírus em felinos silvestres (SCHMITT et al., 2003) e em felídeos domésticos (SOUZA; TEIXEIRA, 2003).

\section{PATOGENIA}

A patogenia da infecção pelo vírus da FeLV é dependente da dinâmica entre fatores virais e relacionados com o hospedeiro, como por exemplo a concentração inoculada, a virulência da linhagem viral, dose e duração da exposição, a presença de doenças concorrentes, a imunidade individual no momento, condições ambientais e a idade (SOUZA; TEIXEIRA, 2003).

Há também o fenômeno da resistência à doença relacionada com a idade. Os gatos com menos de dezesseis semanas de idade são mais suscetíveis à infecção. O gato apresenta uma probabilidade significativamente menor de se tornar infectado pelo vírus da FeLV, caso a primeira exposição ocorra depois de um ano de idade, já que ele tem uma resistência adquirida com a idade (SOUZA; TEIXEIRA, 2003). 
PAULA, E.M.N. et al. Características epidemiológicas da Leucemia Viral Felina. PUBVET, Londrina, V. 8, N. 16, Ed. 265, Art. 1764, Agosto, 2014.

Como outros retrovírus, ao penetrar na célula, o vírus induz à transcrição reversa, processo pelo qual o DNA (acido desoxirribonucleico) viral é copiado a partir do seu RNA, com a participação da enzima transcriptase reversa. As cópias do DNA viral (provírus) migram para o núcleo, que por sua vez é incorporado no DNA cromossômico da célula hospedeira. O provírus integrado à célula é transmitido às células-filhas juntamente com os outros genes. $O$ provírus codifica para o RNA - mensageiro, iniciando a produção de novo RNA viral no citoplasma da célula infectada, e o eventual brotamento das partículas virais da membrana celular. No caso do vírus da FeLV ocorre ainda a síntese ativa de proteínas virais que podem ser encontradas no interior das células infectadas ou no plasma sanguíneo. Para muitas células infectadas, a saída de novos vírions (partículas virais) não significa destruição celular, de modo que existe a contínua produção de proteínas virais e vírions, isto é, a viremia é persistente, fato em que se baseia o diagnóstico imunológico da infecção pelo vírus da leucemia felina (SOUZA; TEIXEIRA, 2003).

A maior característica dos retrovírus é a persistência, que é alcançada por dois mecanismos. O primeiro é a integração de uma cópia em DNA do RNA viral no DNA cromossômico da célula hospedeira, este provírus é mantido por toda a vida da célula. O segundo mecanismo, em nível de hospedeiro, é a evasão das respostas imunes de um estado de anergia ou imunotolerância aos antígenos virais que permitem ao vírus persistir sem impedimentos em seu hospedeiro (SOUZA; TEIXEIRA, 2003).

Para delinear a patogenia da infecção pelo vírus da FeLV, traçou-se uma série de seis estágios:

10 estágio ( 2 a 12 dias): a sequência de replicação do FeLV em gatos começa quando um gato suscetível entra em contato com o vírus pela via oronasal. $\mathrm{Na}$ infecção aguda, o vírus da FeLV se replica inicialmente na células mononucleares (linfócitos e macrófagos), nas tonsilas e tecidos linfoides faringiano, e então, esse é carreado pelo sistema linfático para os linfonodos locais da cabeça e pescoço, onde a replicação é ampliada nos centros foliculares desses linfonodos nos linfócitos B. 
PAULA, E.M.N. et al. Características epidemiológicas da Leucemia Viral Felina. PUBVET, Londrina, V. 8, N. 16, Ed. 265, Art. 1764, Agosto, 2014.

20 estágio ( 2 a 12 dias): um pequeno número de linfócitos e monócitos circulantes se infectam.

$3^{0}$ estágio ( 2 a 12 dias): uma viremia associada à célula (linfócitos e monócitos) se desenvolve dois a doze dias após a infecção, permitindo a disseminação do vírus para a medula óssea, timo, baço, trato gastrointestinal e linfonodos distantes. Os tecidos linfoides abdominais e associados ao intestino (folículos linfoides agregados, placas de Peyer, e outros tecidos linfoides da submucosa) parecem ser os mais importantes.

40 estágio ( 2 a 6 semanas): este é o artigo crítico da infecção aguda, denominado de estágio hemolinfático e intestinal, onde ocorre replicação viral nos neutrófilos, linfócitos e plaquetas ainda na medula óssea e nas células epiteliais intestinais, que são tecidos em constantes mitoses.

O que acontece depois depende de uma competição entre a amplificação do vírus nos precursores granulocíticos e megacariocíticos ativos, e nas células em mitose na medula óssea, nas criptas da mucosa intestinal e nos centros foliculares dos linfonodos e a restrição do vírus pela emergente resposta imune antiviral. A habilidade do sistema imune para impedir essa progressão determina a consequência final e influencia os resultados de vários testes de antígenos.

$5^{\circ}$ estágio ( 4 a 6 semanas): os neutrófilos e plaquetas da medula óssea infectados vão á circulação sanguínea, disseminando-se por todo o corpo, caracterizando assim a viremia.

60 estágio (4 a 6 semanas): o vírus penetra em todos os tecidos epiteliais como glândulas salivares, intestinos e vesícula urinária, estando presente na saliva e na urina. Uma vez introduzido no gato, o vírus progride através de vários tecidos (SOUZA; TEIXEIRA, 2003).

\section{SINAIS CLÍNICOS}

O período de incubação pode variar de meses a anos (BARR; BARR, 2008). O período de incubação para o desenvolvimento do linfoma, leucemia e enfermidades associadas ao vírus da FeLV em gatos naturalmente infectados é 
PAULA, E.M.N. et al. Características epidemiológicas da Leucemia Viral Felina. PUBVET, Londrina, V. 8, N. 16, Ed. 265, Art. 1764, Agosto, 2014.

variável e vai de 3 a 41 meses, com média de 17, 6 meses para o aparecimento dos sinais clínicos citados (VALENZUELA, 2005). Cerca de 30\% dos gatos expostos ao vírus desenvolve uma infecção progressiva e doença associada ao vírus da FeLV e que, cerca do dobro desenvolve uma infecção regressiva (TORRES et al., 2005 citado por AZEVEDO, 2008). Uma vez infectados, $30-50 \%$ destes animais desenvolve uma viremia persistente e doença clínica após um período assintomático de cerca de 80 a 310 dias (em média 171 dias) (TORRES et al., 2005 citado por AZEVEDO, 2008).

Após o desenvolvimento dos sinais clínicos, $80 \%$ dos gatos infectados morrem dentro de 2,5 a 3,5 anos, em comparação com $10 \%$ dos gatos não infectados de idade semelhante (MARI et al., 2004 citado por AZEVEDO, 2008). A prevalência de níveis de antígeno varia de $1-5 \%$ em animais saudáveis e de $15-30 \%$ em animais doentes (POULET et al., 2003 citado por AZEVEDO, 2008).

Os sinais clínicos são diversos devido à natureza imunossupressiva da infecção (TILLEY; SMITH, 2000 citado por COUTINHO, 2009).

As principais manifestações clínicas e laboratoriais da FeLV nos gatos domésticos, podem ser de ordem neoplásica (moléstias proliferativas) ou não neoplásicas (moléstias degenerativas). Dentro das manifestações neoplásicas incluem-se: linfoma mediastinal, multicêntrico, alimentar e formas extranodais; leucemia linfoide, reticuloendoteliose, mieloseeritrêmica, eritroleucemia; leucemias granulocíticas; leucemias megacariocíticas; mielofibrose, mielosclerose/osteosclerose e fibrossarcoma. Já dentro das de ordem não neoplásica estão: síndrome da imunodeficiência adquirida felina; anemias; citopenias (neutropenia persistente ou cíclica/trombocitopenia), mielodisplasia ou síndrome-pré-leucêmica; macrocitose/macroplaquetas; aplasia/hipoplasia da medula óssea; linfadenopatia; aborto/natimortos/infertilidade; glomerulonefrite (deposição de imunocomplexos); distúrbios neurológicos (anisocoria, ataxia, tetraparesia, mudanças do comportamento e incontinência urinária); múltiplas exostoses cartilaginosas, poliartrite (deposição de imunocomplexos); atrofia tímica; 
PAULA, E.M.N. et al. Características epidemiológicas da Leucemia Viral Felina. PUBVET, Londrina, V. 8, N. 16, Ed. 265, Art. 1764, Agosto, 2014.

enterite (SOUZA; TEIXEIRA, 2003). Rinite, conjuntivite, ceratite diarreia persistente - proliferação bacteriana ou fúngica; inflamação parasitária; efeito direto de infeç̧ão sobre as células das criptas; gengivite, estomatite, periodontite; infecções crônicas irresponsivas ou recidivantes da orelha e da pele; febre e debilitação (BARR; BARR, 2008).

A profunda depressão do sistema imune que acompanha a infecção persistente pelo vírus da FeLV tem sido, ultimamente, objeto de intensa pesquisa clínica e experimental (SOUZA; TEIXEIRA, 2003). Uma infecção persistente com este vírus diminui a imunocompetência do hospedeiro gerando neutropenia, disfunção neutrofílica, supressão da blastogênese linfocitária, lise dos linfócitos $T$, depleção dos linfócitos CD4 e CD8, formação de complexos imunes provocando depleção de anticorpos circulantes e hipocomplementomia (SOUZA; TEIXEIRA, 2003). A maioria desses efeitos é mediada pela proteína do envoltório viral com peso molecular de quinze mil, a p15E (SOUZA; TEIXEIRA, 2003). As manifestações clínicas da síndrome de imunodeficiência adquirida felina (FIV) em gatos com FeLV são associadas às infecções bacterianas, virais e parasitárias recidivantes ou persistentes, sendo frequente a ocorrência de faucites, dermatites, abcessos, e otites (SOUZA; TEIXEIRA, 2003). Na FIV induzida pelo vírus da FeLV observa-se também a presença de infecções oportunistas mais severas, levando ao surgimento de doenças como toxoplasmose, hemobartonelose, criptococose e há uma piora do quadro quando, concomitantemente, ocorrem infecções pelo vírus da peritonite infecciosa felina (PIF)ou pelo vírus da imunodeficiência FIV (SOUZA; TEIXEIRA, 2003).

Os vírus da FeLV são depositados na membrana basal dos capilares glomerulares, cujo complemento fixa-se aos imunocomplexos e libera fatores quimiotáxicos, que atraem granulócitos. As enzimas lisossomais são liberadas pelos granulócitos e contribuem para a resposta inflamatória aguda (SOUZA; TEIXEIRA, 2003). Os gatos infectados pelo vírus da FeLV com doença glomerular podem desenvolver a síndrome nefrótica com progressiva hipoalbuminemia, edema e uremia (SOUZA; TEIXEIRA, 2003). 
PAULA, E.M.N. et al. Características epidemiológicas da Leucemia Viral Felina. PUBVET, Londrina, V. 8, N. 16, Ed. 265, Art. 1764, Agosto, 2014.

Os principais distúrbios neurológicos associados a FeLV incluem a paralisia dos nervos ciliares levando à dilatação pupilar persistente, ataxia, paresia dos membros pélvicos ou tetraparalisia (associada ou não ao desenvolvimento de linfoma no canal medular) mudanças comportamentais, hiperestesia durante a palpação da pele e do dorso e incontinência urinária (SOUZA; TEIXEIRA, 2003).

Problemas reprodutivos são comuns em gatos infectados pelo vírus da FeLV (SOUZA; TEIXEIRA, 2003).

A anemia é na maioria das vezes de caráter não regenerativo, podendo ser atribuída às doenças inflamatórias ou desordem primária da medula óssea (SOUZA; TEIXEIRA, 2003).

Quanto às neoplasias associadas a FeLV, as mais comuns são linfoma ou linfossarcoma e o fibrossarcoma (SOUZA e TEIXEIRA, 2003), sendo o linfossarcoma, a mais frequente (COUTINHO, 2008). Esta neoplasia consiste na transformação maligna de linfócitos que residem principalmente nos tecidos linfóides (MORRISON e STARR, 2001). O linfoma é a transformação maligna de linfócitos que residem principalmente nos tecidos linfóides, acometendo os sistemas hemático/linfático/imune; gastrintestinal, renal/urológico; oftálmico; nervoso; pele/exócrino e nasal. Os fibrossarcomas são tumores que podem ter origem no tecido conjuntivo em qualquer ponto do corpo. Habitualmente os fibrossarcomas não fazem metástases, mesmo depois de vários meses; contudo podem estar associados à lise óssea e a uma extensão local (JONES; HUNT; KING, 2000).

Os distúrbios causados pelo vírus da FeLV estão agrupados em moléstias citoproliferativas e moléstias citossupressivas. Em parte, o desfecho específico é determinado pelo subtipo viral de FeLV específico e pela idade do gato na época da infecção (a infecção ocorrente no início da vida do animal tem maiores probabilidades de ser seguida por viremia), estado imunológico do gato, e provavelmente a estrutura genética do gato (JONES; HUNT; KING, 2000). 
PAULA, E.M.N. et al. Características epidemiológicas da Leucemia Viral Felina. PUBVET, Londrina, V. 8, N. 16, Ed. 265, Art. 1764, Agosto, 2014.

Os principais distúrbios resultantes da infecção pelo vírus da FeLV são linfoma maligno com ou sem leucemia que resulta da ativação viral de protooncogenes celulares (JONES; HUNT; KING, 2000). Com base na distribuição anatômica, são identificadas várias formas: (1) linfoma tímico ocorre principalmente em gatos jovens (com menos de três anos de idade), caracterizando-se por uma grande massa tumoral, ou por massas originárias do timo e que substituem esse órgão, e que terminam ocupando o mediastino; (2) linfoma do trato digestivo, observando mais em gatos idosos, caracterizado por tumores sólidos que infiltram-se pelo trato gastrintestinal, linfonodos abdominais, e (frequentemente) fígado, baço e rins; (3) linfoma multicêntrico, habitualmente observado em gatos maduros, caracterizado por um linfoma generalizado que afeta muitos órgãos e tecidos; e (4) linfoma não classificado, que habitualmente apresenta-se na forma de massas tumorais isoladas em tecidos não linfoides, como o olho ou o sistema nervoso central (JONES; HUNT; KING, 2000). Leucemia linfocítica pode ocorrer em conjunto com o linfoma maligno (BARR; BARR, 2008) Leucemias eritróide e mielóide (distúrbios mieloproliferativos) que são as leucemias mais comuns em gatos, e que podem ocorrer conjuntamente (JONES; HUNT; KING, 2000). Mielofibrose é outro desfecho possível. Por causa da enteropatia, patologicamente ocorre atrofia e fusão das vilosidades (JONES; HUNT; KING, 2000); e as lesões intestinais são semelhantes às observadas com infecção pelo parvovírus felino (síndrome semelhante à panleucopenia felina) (BARR; BARR, 2008). A imunossupressão pode ser tão grave que filhotes de gatos morrem, manifestando a atrofia tímica e depleção linfoide, no exame post mortem. Vão ocorrer infiltrados linfocíticos, e plasmocíticos nas gengivas, nos linfonodos, em outros tecidos linfoides, baço, rins, e no fígado (SOUZA; TEIXEIRA, 2003).

\section{DIAGNÓSTICO}

O diagnóstico da infecção da FeLV é feito pela associação do exame clínico, geralmente inconclusivo, com exames laboratoriais complementares (MIYAZAWA, 2002 citado por TEIXEIRA et al., 2007). 
PAULA, E.M.N. et al. Características epidemiológicas da Leucemia Viral Felina. PUBVET, Londrina, V. 8, N. 16, Ed. 265, Art. 1764, Agosto, 2014.

O diagnóstico pode ser dividido em primário e secundário. Sobre o diagnóstico primário afirma que os sinais clínicos variam muito e inclui dispneia, letargia, anorexia, febre, gengivite/estomatite. No exame físico são relatados evidências de derrame pleural, membranas mucosas pálidas, anomalias intra-oculares, massas intra-abdominais palpáveis, e organomegalia (baço, fígado, rins) (NORSWORTHY, 2006), sendo consenso de alguns autores (SHERDING, 1998).

No hemograma e perfil bioquímico tem achados que incluem anemia regenerativa normocíticanormocrômica ou arregenerativamacrocítica (SHERDING, 1998); também são achados azotemia, aumento das enzimas hepáticas e bilirrubina sérica aumentada (NORSWORTHY, 2006). Já os testes para detecção de antígenos (vírus) serão positivos, dependendo da forma clínica da doença e dos órgãos envolvidos.

Sobre o diagnóstico secundário, a citologia de medula óssea pode revelar displasia óssea, mesmo quando o esfregaço de sangue periférico é normal (NORSWORTHY, 2006). Um aspirado de medula óssea é um tecido de excelente fonte para o teste da FeLV, especialmente através do teste de imunofluorescência direta (RIFD), porque o vírus pode ser sequestrado na medula óssea de alguns gatos que são negativos nos exames de sangue (NORSWORTHY, 2006). A análise do líquido pleural revela frequentemente linfoblastos em um fluido com alto teor de proteína e contagem de células total elevado (NORSWORTHY, 2006). A citologia de aspiração revela frequentemente linfoblastos em órgãos aumentados e massas abdominais não identificadas (NORSWORTHY, 2006)

No diagnóstico laboratorial pode-se encontrar uma anemia geralmente grave; linfopenia; neutropenia que pode ocorrer em resposta a infecções secundárias; trombocitopenia e anemia hemolítica imunomediada que pode ocorrer secundária a complexos imunes. Os achados da urinálise e do perfil bioquímico sérico dependerão do sistema acometido (BARR; BARR, 2008). Análise de fluido pleural frequentemente revela linfoblastos num fluido com alto teor protéico, e alta contagem de células totais (SOUZA; TEIXEIRA, 2003). 
PAULA, E.M.N. et al. Características epidemiológicas da Leucemia Viral Felina. PUBVET, Londrina, V. 8, N. 16, Ed. 265, Art. 1764, Agosto, 2014.

A presença do vírus pode ser demonstrada por fotografias elétronmicroscópicas de partículas replicantes do tipo C. É empregado um teste de anticorpo fluorescente para a detecção do antígeno em leucócitos em esfregaços sanguíneos (HARDY et al., 1973 citado por JONES; HUNT; KING, 2000).

A maioria dos testes diagnósticos de rotina usa anticorpos poli ou monoclonais contra a proteína mais importante do núcleo do vírus da FeLV, a p24. As técnicas utilizadas para detecção da proteína viral são a imunomigração rápida, a imunofluorescência direta (RIFD) e o teste imunoadsorção enzimática (ELISA) sendo os dois últimos os mais utilizados (SOUZA; TEIXEIRA, 2003).

O teste ELISA apresenta alta sensibilidade, especificidade e praticidade. O teste ELISA comercialmente empregado e denominado, "Snap-CITE combo FeLV/FIV TESTKIT, idexx Systems, Portland USA" contém anticorpos monoclonais anti-FeLV p27 e antígeno FIV p24. Ele é capaz de detectar o vírus precocemente (a partir do segundo estágio) no soro, plasma ou sangue, enquanto que os outros testes só o detectam a partir do desenvolvimento da viremia. O soro é o meio preferido para realização, porque resulta em poucos resultados falsos positivos e negativos. O teste ELISA usa uma alteração de cor enzimática, por ligação a anticorpos, para a detecção do antígenos p27 (SOUZA; TEIXEIRA, 2003). Um único teste positivo não pode prever que gatos ficarão persistentemente virêmicos; testar novamente 12 semanas depois; resultados falso-positivos são mais comuns quando se usa sangue total em vez de plasma (BARR; BARR, 2008). Alguns gatos são persistentemente positivos ao ELISA e negativos para o RIFD (SOUZA; TEIXEIRA, 2003). Os resultados positivos coincidem nos dois testes em aproximadamente $70 \%$ dos casos (SOUZA; TEIXEIRA, 2003). Quando eles são diferentes, sendo o teste ELISA positivo e o RIFD negativo, pode ter vários significados, como um falsopositivo ou negativo, ou o animal ainda está em estágio inicial da infecção, portanto deve repetir o exame após a infecção ou nunca teve contato, no entanto, no caso de duplo positivo, o animal desenvolveu viremia (SOUZA; 
PAULA, E.M.N. et al. Características epidemiológicas da Leucemia Viral Felina. PUBVET, Londrina, V. 8, N. 16, Ed. 265, Art. 1764, Agosto, 2014.

TEIXEIRA, 2003). Nenhum teste detecta gatos vacinados contra o vírus da FeLV, porque a vacina induz anticorpos contra o antígeno gp70, e não contra o antígeno p27 (BARR; BARR, 2008).

A sensibilidade do teste ELISA para detectar o antígeno da FeLV na amostra é próxima de $100 \%$, sem diferença significativa em amostras idênticas entre os resultados desse teste e de PCR (SOUZA; TEIXEIRA, 2003).

A RIFD identifica o antígeno p27 do VLF em leucócitos e plaquetas em esfregaços de sangue total ou preparações da cama leucocitária (BARR; BARR, 2008). É por isso que esse teste só é capaz de detectar o vírus após a viremia (SOUZA; TEIXEIRA, 2003). Resultados positivos indicam uma infecção produtiva em células da medula óssea; $97 \%$ dos gatos positivos para o AIF permanecem infectados de forma persistente e virêmicos pelo resto da vida (BARR; BARR, 2008). Nesses casos de resultado positivo o gato estará contagioso (SOUZA; TEIXEIRA, 2003). Em geral, o antígeno p27 pode ser detectado por volta de quatro semanas depois da infecção, mas pode ser que leve até doze semanas para se obter um teste positivo (BARR; BARR, 2008). No caso de um resultado negativo, o vírus pode estar em estado de latência ou ainda não ocorreu a viremia, ou então, o animal realmente não apresenta infecção. Um resultado falso negativo pode ocorrer devido à presença de neutropenia e trombocitopenia (SOUZA; TEIXEIRA, 2003).

\section{ACHADOS ANATOMOPATOLÓgICOS}

Os distúrbios neoplásicos resultantes da infecção pelo vírus da FeLV são linfoma maligno com ou sem leucemia que resulta na ativação viral de protooncogenes celulares. Com base na distribuição anatômica, os linfomas são identificados de várias formas: linfoma tímico que ocorre principalmente em gatos jovens (com menos de três anos de idade), caracterizando-se por uma grande massa tumoral ou por massas originárias do timo e que substituem esse órgão, e que terminam ocupando o mediastino; linfoma do trato digestivo, observado mais em gatos idosos, caracterizado por tumores sólidos que infiltram-se pelo trato gastrintestinal, linfonodos abdominais, e 
PAULA, E.M.N. et al. Características epidemiológicas da Leucemia Viral Felina. PUBVET, Londrina, V. 8, N. 16, Ed. 265, Art. 1764, Agosto, 2014.

frequentemente no fígado, baço e rim; linfoma multicêntrico, habitualmente observado em gatos maduros, caracterizado por um linfoma generalizado que afeta muitos órgãos e tecidos; e linfoma não classificado, que habitualmente apresenta-se na forma de massas tumorais isoladas em tecidos não linfóides, como o olho ou o sistema nervoso central (JONES et al., 2000).

\section{DIAGNÓSTICO DIFERENCIAL}

O diagnóstico diferencial para FeLV deve ser feito para infecções bacterianas, parasitárias, virais e doenças neoplásicas não virais (BARR; BARR, 2008).

O vírus da FeLV é responsável pela ocorrência de diversas neoplasias hematopoiéticas em gatos (MACKEY, 1975 citado por CÁPUA et al., 2005) e $70 \%$ dos linfomas felinos estão casualmente associados a FeLV (HELFAND; VAIL, 1998 citado por CÁPUA et al., 2005), logo deve se considerar neoplasias hematopoiéticas como diagnóstico diferencial.

Existe também uma relação entre o vírus da FIV, um Lentivírus linfotrópico, e a incidência do linfoma (VODERHAAR; MORRISON, 1998 citado por CÁPUA et al., 2005); então outro diagnóstico diferencial é a infecção por FIV.

O diagnóstico diferencial entre FIV e FeLV é muito difícil de realizar, uma vez que os sinais clínicos associados são muito semelhantes e muito inespecíficos, o que torna de grande utilidade na prática clínica, o kit de diagnóstico comum ao FIV e ao FeLV (ARJONA et al.,2007; HARTMANN et al., 2007 citado por AZEVEDO, 2009). A PIF pode ser diagnóstico diferencial de FeLV (AMELIA, 2006).

\section{TRATAMENTO}

Ainda não existe um tratamento efetivo provado para o vírus da FeLV, mas a pesquisa e os experimentos terapêuticos encontram-se em progresso, utilizando várias drogas moduladores imunes e antivirais (SHERDING, 1998). O sucesso do tratamento das infecções retrovirais tem requerido um melhor 
PAULA, E.M.N. et al. Características epidemiológicas da Leucemia Viral Felina. PUBVET, Londrina, V. 8, N. 16, Ed. 265, Art. 1764, Agosto, 2014.

entendimento de seu enorme potencial para adaptação genética (OVERBAUG; BANGHAM, 2001 citado por SOUZA; TEIXEIRA, 2003).

A decisão de que se deva ou não iniciar o tratamento paliativo e sintomático nos gatos com infecções concorrentes não depende apenas da positividade do exame para o vírus da FeLV, embora a infecção por esse retrovírus possa influenciar no prognóstico do paciente (LEVI; RICHARDS; EDWARDS, 2001 citado por SOUZA; TEIXEIRA, 2003).

A terapia de suporte (como antibióticos para infecções secundárias, fluidoterapia e suporte nutricional) pode prolongar a sobrevivência em pacientes selecionados. O linfoma não-tratado é geralmente fatal de um a dois meses, mas uma quimioterapia anticâncer pode induzir a remissão em muitos gatos. O prognóstico para gatos com anemia não-regenerativa e doença mieloproliferativa relacionadas ao vírus da FelV é mau, embora as transfusões sanguíneas possam prolongar a sobrevivência (SHERDING, 1998).

Transfusões de sangue - suporte de emergência; podem ser necessárias múltiplas transfusões; a transferência passiva de anticorpo reduz a antigemia do vírus da FelV em alguns gatos; portanto, é válida a imunização com vacinas contra o vírus da FelV de gatos doadores de sangue (BARR, 2008).

Muitos casos de linfoma em gatos positivos para FeLV tem sido tratados com êxito pela quimioterapia combinada. São mais comumente utilizados os regimes que usam a vincristina, ciclofosfamida e prednisona. Os períodos de remissão se prologam, em média por três a quatro meses, mas alguns gatos podem permanecer em remissão por período muito mais prolongado (COUTINHO, 2008).

Os corticosteroides tem uso importante na terapia do linfoma e possuem um efeito benéfico para neoplasias do sistema nervoso central, por sua capacidade de cruzamento da barreira hematoencefálica (COUTINHO, 2008).

Suas ações benéficas em outros tumores sólidos provavelmente estão relacionadas mais aos efeitos antiinflamatórios do que a efeitos anti-tumorais diretos (COUTINHO, 2008). 
PAULA, E.M.N. et al. Características epidemiológicas da Leucemia Viral Felina. PUBVET, Londrina, V. 8, N. 16, Ed. 265, Art. 1764, Agosto, 2014.

Os protótipos futuros desenvolvidos para o tratamento do retrovírus da AIDS humana serão provavelmente explorados nos gatos com o vírus da FelV (SHERDING, 1998).

Um outro método de tratamento, utilizado para melhorar a condição de vida do gato seria acupuntura e homeopatia.

A medicina tradicional chinesa (MTC) enfatiza que o equilíbrio é a chave para a saúde, sendo que a doença ocorre quando há desarmonia neste equilíbrio (COUTINHO, 2008).

O tratamento básico na MTC é de aumentar esta imunidade através do fortalecimento dos órgãos que na medicina são caracterizados como responsáveis pela imunidade, no caso o rim em primeiro lugar, os pulmões e o baço-pâncrea (COUTINHO, 2008).

A acupuntura, associada a drogas para prevenir as náuseas e vômitos, parece aliviar estes sintomas induzidos pela quimioterapia. Apesar do advento de novas drogas que controlam os efeitos colaterais relacionados à quimioterapia, muitos doentes com câncer continuam a sentir estes efeitos desagradáveis, o que pode prejudicar a qualidade de vida, causando sofrimento emocional, e agravando os sintomas relacionados com câncer como a perda de peso, letargia e fraqueza (COUTINHO, 2008).

$\mathrm{Na}$ medicina antroposófica, o extrato total do Viscum Álbum foi desenvolvido para tratar doentes com câncer. O mais antigo desses produtos é Iscador. Embora Iscador seja considerado como uma terapia complementar é a droga oncológica mais comumente utilizada na Alemanha (COUTINHO, 2008).

Mistletoe (Viscum album) é uma planta semiparasita que cresce em vários tipos de árvores, incluindo macieiras, carvalhos, pinheiro, vidoeiro do norte da Europa ao noroeste da África, estendendo-se à Ásia Central e Japão (COUTINHO, 2008).

Extratos de Viscum album tem mostrado matar células cancerígenas em laboratório e estimular o sistema imunológico. Por esta razão, o Viscum album tem sido classificado como um tipo de substância que estimula o organismo a responder a infecções e doenças, e que protege o DNA das células brancas do 
PAULA, E.M.N. et al. Características epidemiológicas da Leucemia Viral Felina. PUBVET, Londrina, V. 8, N. 16, Ed. 265, Art. 1764, Agosto, 2014.

sangue, incluindo células que são expostas á quimioterapia (COUTINHO, 2008).

\section{PROGNÓSTICO}

O prognóstico para os gatos virêmicos persistentemente pelo vírus da FeLV é reservado: em um período de dois a três anos, a maioria dos animais vem a óbito (SOUZA; TEIXEIRA, 2003).

\section{MEDIDAS DE CONTROLE E PREVENÇÃo}

Devido às devastadoras consequências da infecção pelo vírus da FeLV e à sua prevalência na população de gatos, sua prevenção possui uma importância vital (SHERDING, 1998). O paciente FeLV positivo deve ser mantido dentro de casa tanto para evitar a transmissão para outros gatos como para poupá-lo de ter acesso às doenças oportunistas como às dermatofitoses, diarreias entre outras. Assim como as fêmeas sabidamente positivas, devem ser excluídas da reprodução devido às formas de transmissão (TILLEY; SMITH, 2000 citado por COUTINHO, 2009). Uma dieta rica em nutrientes balanceada e completa para felinos é essencial. Carne crua, ovos e leite não pasteurizado devem ser evitados, em virtude do maior risco de infecções bacterianas e parasitárias em gatos imunossuprimidos. Uma avaliação do estado geral do felino deve ser realizada semestralmente pelo veterinário (LEVY, 2000 citado por SOUZA; TEIXEIRA, 2003).

A FeLV é considerada uma doença mais comum entre gatos que vivem em grupos e mantem contato amigável (HAGIWARA; JORGE; STRICAGNOLO, 2007).

A introdução de um novo gato em criatórios deve sempre ser precedida pela realização dos testes de FeLV e FIV, como meio de controlar a disseminação (HAGIWARA; JORGE; STRICAGNOLO, 2007). O contato com gatos de rua deve ser evitado, pois esses animais, de origem desconhecida, ao brigarem por território ou por fêmeas, podem transmitir o vírus (HAGIWARA; JORGE; STRICAGNOLO, 2007). 
PAULA, E.M.N. et al. Características epidemiológicas da Leucemia Viral Felina. PUBVET, Londrina, V. 8, N. 16, Ed. 265, Art. 1764, Agosto, 2014.

Outras medidas preventivas incluem a vacinação de gatos individuais para reduzir a suscetibilidade e as medidas de controle para reduzir a disseminação do vírus da FeLV nos gatis (SHERDING, 1998).

A profilaxia da FeLV nos felinos em grupo se baseia na identificação e no isolamento dos animais infectados e na vacinação daqueles expostos ao risco (HAGIWARA; JORGE; STRICAGNOLO, 2007). Gatos FeLV negativos devem apenas co-habitar com animais igualmente negativos (COHN, 2007b citado por AZEVEDO, 2008).

Existem vacinas disponíveis, muito úteis para efetuar um bom controle da doença (POULET et al., 2003 citado por AZEVEDO, 2008) e são responsáveis pela diminuição da incidência da FeLV que se tem observado desde a década de 80 (LOUWERENS et al., 2005 citado por AZEVEDO, 2008)

A efetividade da vacinação com o vírus da FeLV e os métodos utilizados para demonstrar a eficácia são controvertidos e assuntos não-resolvidos, em parte devido à maior parte das dados de eficácia disponíveis terem sido fornecidos por fabricantes em vez de por pesquisadores imparciais (BICHARD, 1998).

Em geral, os gatos vacinados expostos ao vírus frequentemente desenvolvem viremia transitória e algumas vezes a infecção latente apesar da vacinação; no entanto, a maioria dos gatos vacinados fica aparentemente protegida contra viremia persistente e, portanto contra a doença relacionada ao vírus da FeLV (BICHARD, 1998).

As infecções latentes em gatos vacinados expostos são menos frequentes e geralmente não persistem, comparados com os gatos não-vacinados. No entanto, pode-se superdestacar esse benefício da vacinação, à medida que a importância clínica das infecções latentes é provavelmente mínima de qualquer forma (BICHARD, 1998).

Como parâmetro geral para discutir a expectativa de vacinação com os proprietários de animais, espera-se que 70 a $90 \%$ dos gatos vacinados sejam protegidos contra infecção por FeLV persistente. Pode ser necessário modificar 
PAULA, E.M.N. et al. Características epidemiológicas da Leucemia Viral Felina. PUBVET, Londrina, V. 8, N. 16, Ed. 265, Art. 1764, Agosto, 2014.

isso à medida que se tornem disponíveis dados de eficácia adicionais (BICHARD, 1998).

Nos programas de vacinação deve ter-se em conta a vacinação de todos os gatos que tem acesso à rua, devido ao possível contato com animais FeLV positivos, assim como dos animais que coabitam com animais infectados ou com estado portador desconhecido. No entanto, mesmo os gatos vacinados devem ser separados de animais FeLV positivos (SPARKES, 2003 citado por AZEVEDO, 2008)

Deve também ser efetuada uma desinfecção de rotina dos locais contaminados, com compostos de amônia quaternários, outros desinfetantes, sabões, etc. Na prevenção hospitalar, devem ser tomados cuidados de modo a evitar a transmissão através de fômites, comedouros, bebedouros, caixas de litter, camas ou até mesmo através dos auxiliares, enfermeiros ou médicos veterinários (HARTMANN, 2004 citado por AZEVEDO, 2008).

\section{CONCLUSÃO}

Conclui-se que a FeLV é uma doença viral grave com caráter imunodeficiente podendo levar a sérios prejuízos na saúde e rendimento dos animais. O tratamento é de acordo com as doenças secundárias e o prognóstico é ruim. Portanto, deve haver uma adequada prevenção, com vacinação, evitando-se a aglomeração e o acesso de gatos à rua. $O$ controle populacional é também de extrema importância para evitar a disseminação descontrolada da doença.

\section{REFERÊNCIAS BIBLIOGRÁFICAS}

AMELIA, M. J. M. Peritonitis infecciosa feline en España: diagnostic y prevención. 2006. Disponível em: <http://www.impocan .com/ impocan/documentos/Primucell_Pif.pdf >. Acessoem: 8 set. 2013.

AZEVEDO, V. L. N. Lesões de reabsorçãoodontoclástica feline e a suaassociação a gatospositivosaos virus da leukemia (felv) e da imunodeficiência (fiv) felinas. Dissertação (mestrado em Medicina Veterinária). Disponível em: <http://www.repository.utl.pt/ bitstream/10400.5/859/1/Azevedo.pdf>. Acessoem: 7 set. 2013. 
BARbosa, F. C.; Christianne, M. P. T.; WALDEMARin, K. C. A. Prevalência de leucemia felina em gatos domésticos de Uberlândia - MG. Disponível em: $<$ http://bases.bireme.br/cgi-bin/wxislind.exe /iah/online/?IsisScript=iah. xis\&src=google\&base $=$ LILACS\&lang=p\&nextAction=Ink\&exprSearc $\mathrm{h}=360703$ \&indexSearch=ID>. Acesso em: 17 out. 2013.

BARR, M. C.; BARR, S. C. Infecção pelo vírus da leucemia felina. In: TILLEY, L. P.; SMITH JUNIOR, F. W. K. Consulta Veterinária em 5 minutos: espécies canina e felina. 3. ed. Barueri: Manole, 2008. p. 814-815.

BLEICH, I. M. Leucemia Felina: diagnóstico e profilaxia. Cães e Gatos: Revista do Clínico, Pet Shop e Revenda, Porto Feliz, v. 3, n. 21, p. 22-23, jul./ago. 1988.

CÁPUA, M. L. B.; NAKAGE, A. P. M.; ZILIOTTO, L.; COELHO, P. S.; SANTANA, A. E. Linfoma mediastinal em felino persa: relato de caso. Ars Veterinária, Jaboticabal, SP, v. 21, n. 3, p. 311-314, 2005.

COUTINHO, A. C. R. O Tratamento da Leucemia Viral Felina através da Acupuntura. Disponível em: <http://www.homeopatia jacquelinepeker.com.br monografias/Monografia_Andrea_prata.pdf>. Acesso em: 14 out. 2013.

HAGIWARA, M. K.; JUNQUEIRA-JORGE, J.; STRICAGNOLO, C. Infecção pelo Vírus da Leucemia Felina em gatos de diversas cidades do Brasil. Clínica Veterinária, São Paulo, n. 66, p.44-47, jan./fev. 2007.

JARRET, O.; HOSIE, M. J. Infecção pelo vírus da leucemia felina. In: CHANDLER, E. A.; GASKELL, C. J.; GASKELL, R. M. Clínica e terapêutica em felinos. 3. ed. São Paulo: Roca, 2006. Cap. 23, p. 487-493.

JARRET, O.; Infecção pelo vírus da leucemia felina. In: Terapêutica e Medicina Felina São Paulo: Manole, 1988.

JONES, T. C.; HUNT, R. D.; KING, N. W. Patologia Veterinária. 6 ed. Barueri: Manole, 2000.

MEINERZ, A. R. M. et al. Frequência do Vírus da Leucemia Felina (VLFe) em FELINOS. Ciência Animal Brasileira, Goiânia, v. 11, n. 1, p.90-93, 2010.

MORRISON, W. B.; STARR, R. M..Vaccine-associated feline sarcomas. Journal Of The American Veterinary Medical Association, West Lafayette, p. 697-702. 1 mar. 2001

MURPHY, F. A. et al. Veterinary Virology. 3. ed. California: An Imprint Of Elsevier, 1999.

NORSWORTHY, G. D. Felineleukemiavirusdisease. In: NORSWORTHY, G. D.; CRYSTAL, M. A.; GRACE, S.; TILLEY L. P. The feline patient. 3 ed. Arnes, Iwoa. J. wiley, 2006. Cap. 45, p. 99101.

SCHMITT A.C., REISCHAK D., CAVLAC C.L., MONFORTE C.H.L., COUTO F.T., ALMEIDA A.B.P.F., SANTOS D.G.G., SOUZA L., ALVES C. \& VECCHI K. Infecção pelos vírus da leucemia felina e da peritonite infecciosa felina em felídeo selvagem de vida livre e de cativeiro da região do pantanal mato-grossense. Acta Science Veterinariae, v. 31, n. 3, p. 185-188, 2003.

SHERDING, R. G. Vírus da leucemia felina. In: BIRCHARD, S. J.; SHERDING, R. G. Manual Saunders: clínica de pequenos animais. São Paulo: Roca, 1998. Cap. 1, p. 91-100. 
SOUZA, H. J M.; TEIXEIRA, C. H. R. Leucemia Viral Felina. In: SOUZA, J. M. Coletânea em medicina e cirurgia felina. Rio de Janeiro: Lf Livros, 2003. p. 251-267.

SOUZA, H. J. M. Estudo epidemiológico de infecções pelo vírus da leucemia e/ou imunodeficiência felina, em gatos domésticos do município do Rio de Janeiro. Clínica Veterinária: Revista de Educação Continuada do Clínico Veterinário de Pequenos Animais, São Paulo, v. 7, n. 36, p. 14-20, jan./fev. 2002.

SWIFT, W. B. FeLV ou Vírus da Leucemia Felina. Animals, jan./fev., 1998.

TEIXEIRA, B. M. et al. Ocorrência do vírus da imunodeficiência felina e do vírus da leucemia felina em gatos domésticos mantidos em abrigos no município de Belo Horizonte. Arq. Bras. Med. Vet. Zootec., Belo Horizonte, v. 59, n. 4, p. 939-942, 2007.

VALENZUELA, M. C. Manifestações clínicas de La infeccion por Retrovirus Felinos (vírus leucemia e inmunodeficiência felina), 2005 